\title{
Bioactive Low Molecular Weight Compounds in Two Traditional Spanish Products
}

\author{
María Luisa Timón*, Emilio José Galea, Ana Isabel Andrés, María Jesús Petrón \\ Department of Animal Production and Food Science, School of Agricultural Engineering, University of Extremadura, Badajoz, \\ Spain. \\ Email: ${ }^{*}$ mltimon@unex.es
}

Received June $19^{\text {th }}, 2013$; revised July $19^{\text {th }}, 2013$; accepted July $26^{\text {th }}, 2013$

Copyright (C 2013 María Luisa Timón et al. This is an open access article distributed under the Creative Commons Attribution License, which permits unrestricted use, distribution, and reproduction in any medium, provided the original work is properly cited.

\begin{abstract}
The aim of this work focuses on the study of low molecular weight (LMW) compounds with antioxidant and antihypertensive effect in Iberian ham and La Serena cheese, two traditional products in Spain, in comparison to cured ham and matured Ewe's milk cheese. Proteolysis parameters were studied, LMW compounds were isolated and their antioxidant and antihypertensive activity was analyzed. Results showed that a more intense proteolysis, expressed as peptidic nitrogen $(\mathrm{PN})$, in Iberian ham $(\mathrm{p}<0.001)$, can cause higher antioxidant activity in this product for both DPPH radical scavenging $(p<0.001)$ and metal chelating effect $(p<0.001)$. However, a more intense proteolysis in La Serena cheese, expressed as non protein nitrogen (NPN) $(\mathrm{p}<0.001)$ and PN $(\mathrm{p}<0.001)$, did not promote higher antioxidant activity in this cheese. On the other hand, no differences were found for antihypertensive activity, expressed as angiotensin I-converting enzyme (ACE) inhibitory activity, in both type of hams or cheese.
\end{abstract}

Keywords: Bioactive Compound; Proteolysis; Traditional Food; Antioxidant Activity; Antihypertensive Activity

\section{Introduction}

Iberian ham and La Serena cheese are traditional products of great importance in the Spanish market. The origin of the raw material and the ripening process of these products make them different to other cured hams and ewes' milk cheeses [1,2], thus being protected by a designation of origin (PDO). Iberian ham and La Serena cheese are very popular for consumers due to their exceptional sensory characteristics $[3,4]$. However, their consumption is being affected by other considerations related to health and welfare of consumers such as fat, saturated fatty acid, cholesterol and sodium contents $[1,4]$.

Nevertheless, several researches insist on demonstrating that traditional products derived from animals with an extensive and special manufacturing process, as Iberian ham or La Serena cheese, could be considered healthy from a nutritional point of view because of the high proportion of monounsaturated fatty acids (MFA), conjugated linoleic acid (CLA) or terpenes $[2,4,5]$. In this sense, proteolysis phenomena occurring during processing of these traditional products could cause the ge-

\footnotetext{
${ }^{*}$ Corresponding author.
}

neration of active peptides with beneficial health effects. Therefore, this fact could be of great interest since it would help to improve the commercial image of these products.

Many active peptides have been isolated from proteins of animal origin such as milk, dairy products, raw meat or meat products [6]. Some of the most important bioactive peptides are the angiotensin I-converting enzyme (ACE) inhibitory peptides, which play an important role in the regulation of blood pressure. Milk proteins as source of ACE inhibitory peptides are the most studied ones. In this sense, ACE inhibitory activity has been tested in caseins $[7,8]$, fermented milk [8], whey proteins $[9,10]$ and fresh or matured cheeses [11,12]. However, many researches have also showed ACE inhibitory activity on meat protein hydrolyzates [13-15]. Moreover, several authors found this activity in cured ham where some dipeptides were generated during processing [16, 17]. Recently, Vastag et al. [18] suggested that final compounds of proteolysis in fermented sausages were responsible for the ACE inhibitory activity of the products.

On the other hand, it is known that some peptides derived from milk and meat proteins show capacity to 
inhibit oxidative damages. In this sense, Suetsuna et al. [19] found free radical scavenging activity after peptidic digestion of milk caseins, results that were later corroborated by Rival et al. [20] and Sakanaka et al. [21]. Moreover, whey proteins also showed antioxidant activity as it was reported in several researches [22,23]. Recently, Farvin et al. [24] described antioxidant activity of yoghurt peptides released during fermentation of milk by lactic acid bacteria. Other studies have investigated antioxidant properties of active peptides from meat as pork hidrolyzates [25]. Moreover, some authors were able to isolate peptides with antioxidant activity generated in fermented and cured sausages [18,26-28].

The aim of this work focuses on the study of peptides with antioxidant and antihypertensive effect in Iberian ham and La Serena cheese generated during processing, in comparison to cured ham and matured ewe's milk cheese.

\section{Material and Methods}

\subsection{Samples}

Ham and cheese samples were purchased from a local supermarket in Badajoz, Spain. Ham samples $(\mathrm{n}=20)$ were obtained from Iberian cured ham $(\mathrm{IH})(\mathrm{n}=10)$ and non Iberian cured ham $(\mathrm{CH})(\mathrm{n}=10)$, with 24 months and 8 months process, respectively. On the same way, cheese samples were obtained from La Serena cheese (SC) $(n=10)$ and matured ewe's milk cheese (MC), made with plant and animal rennet, respectively. Samples were then minced, vacuum packed, and stored at $-80^{\circ} \mathrm{C}$ until analysis.

\subsection{Total Protein Content Determination}

Total protein content was expressed as percentage of dry matter and calculated following the Kjeldahl method (multiplying nitrogen percentage by a factor, 6.25 for ham and 6.38 for cheese) (ISO 937) [29].

\subsection{Non Protein Nitrogen, Peptidic Nitrogen and Amino Acid Nitrogen Analysis}

Non-protein nitrogen (NPN) was determined by Nessler method using $4 \mathrm{~g}$ of sample after protein precipitation with $0.6 \mathrm{M}$ perchloric acid. Amino acid nitrogen (AN) was determined from the $0.6 \mathrm{M}$ perchloric acid protein precipitation fraction after peptide precipitation with $10 \%$ sulfosalicilic acid [30]. The determination of peptidic nitrogen (PN) was made as AN prior to acid hydrolysis of the NPN fraction with $6 \mathrm{~N} \mathrm{HCl}\left(24 \mathrm{~h}\right.$ at $\left.120^{\circ} \mathrm{C}\right)$ and correction for AN.

\subsection{Extraction of Low Molecular Weight (LMW) Compounds from Ham}

LMW compounds (molecular weight less than $3 \mathrm{kDa}$ ) were extracted following the method developed by Broncano et al. [27]. Frozen ham samples (2.5 g) were homogenised in $12.5 \mathrm{ml}$ of Perchloric acid $(50 \mathrm{ml} / \mathrm{l})$ in centrifuge tubes for $2 \mathrm{~min}$ on ice. The homogenate was centrifuged at $10,000 \mathrm{~g}$ for $12 \mathrm{~min}$ at $4^{\circ} \mathrm{C}$ and the supernatant was collected and filtered using a cellulose acetate filter of $0.2 \mu \mathrm{m}$ pore size (ALBET LabScience, Barcelona, Spain). The extracts were then neutralised ( $\mathrm{pH} 7.0)$ using potassium hydroxide $(\mathrm{KOH})$. The resulting salt was eliminated using a cellulose acetate filter of $0.1 \mu \mathrm{m}$ size pore filter (Albet LabScience, Barcelona, Spain). The supernatant was submitted to ultrafiltration with $3 \mathrm{kDa}$ cut-off (Millipore Amicon Ultra 15 Centrifugal filter Units, Bedford, United Kingdom) at $4000 \mathrm{~g}$ for $30 \mathrm{~min}$. Ham extracts were finally lyophilized and stored at $-20^{\circ} \mathrm{C}$ until analysis. Freeze-dried extracts were dissolved in milliQ water at a concentration of $10 \mathrm{mg} / \mathrm{ml}$ in order to determine the antioxidant and antihypertensive activities.

\subsection{Extraction of Low Molecular Weight (LMW) Compounds from Cheese}

Extracts were obtained following the procedure described by Gómez-Ruiz et al. [31]. Cheese was homogenised with twice its weight of Milli-Q water (Merk Millipore, Bedford, United Kingdom). The homogenate was held for $60 \mathrm{~min}$ at $40^{\circ} \mathrm{C}$, and then, centrifuged at $3800 \mathrm{~g}$ and $4^{\circ} \mathrm{C}$ for $30 \mathrm{~min}$. The resulting supernatant was filtered through a cellulose filter (diameter $5 \mu \mathrm{m}$ ) (Albet, Barcelona, Spain). Permeate was centrifuged at 10,000 $\mathrm{g}$ and $4^{\circ} \mathrm{C}$ for $20 \mathrm{~min}$, and the supernatant was filtered through glass wool and cellulose filter (diameter $0.2 \mu \mathrm{m}$ ) (Albet, Barcelona, Spain). Then, it was ultrafiltered on an AMICON ULTRA tube with $3 \mathrm{kDa}$ pore size (Centripep, Amicon, Bedford, United Kingdom). Finally, permeate was freeze-dried, dissolved in milliQ water at a concentration of $10 \mathrm{mg} / \mathrm{ml}$ and kept at $-20^{\circ} \mathrm{C}$ until use.

\subsection{Determination of DPPH Radical Scavenging Activity (RSA)}

The RSA of extracts was determined according to the method described by Broncano et al. [27]. A $500 \mu \mathrm{l}$ test sample was mixed with $500 \mu$ of ethanol (99.5\%) and $125 \mu$ of DPPH (99.5\%, with $0.01 \%$ DPPH). This mixture was kept in the dark at room temperature for $60 \mathrm{~min}$ before measuring absorbance at $517 \mathrm{~nm}$. Radical scavenging activity (RSA, in percent) was calculated as follows:

$$
\mathrm{RSA}=\left(\left(\mathrm{A}_{\text {control }}-\mathrm{A}_{\text {sample }}\right) / \mathrm{A}_{\text {control }}\right) \times 100
$$

where $\mathrm{A}_{\text {sample }}$ is the absorbance of the test sample and $A_{\text {control }}$ is the absorbance of distilled water.

\subsection{Metal Chelating Assay (MQA)}

The MQA of the extract was determined using a ferrous 
ion chelating assay [27]. An $800 \mu \mathrm{l}$ test sample was added with $10 \mu \mathrm{FeCl}_{2}(2 \mathrm{mM})$ and $20 \mu \mathrm{l}$ ferrozine (5 $\mathrm{mM})$. The mixture was vortexed and kept at room temperature for $10 \mathrm{~min}$ prior to measuring absorbance at 562 $\mathrm{nm}$. Chelating effect (in percent) was calculated as follows:

$$
\text { Chelating effect }=\left(\left(\mathrm{A}_{\text {control }}-\mathrm{A}_{\text {sample }}\right) / \mathrm{A}_{\text {control }}\right) \times 100
$$

where $A_{\text {sample }}$ is the absorbance of the test sample and $\mathrm{A}_{\text {control }}$ is the absorbance of distilled water.

\subsection{Determination of ACE-Inhibitory (ACEI) Activity}

ACEI activity was determined according to the method described by Ong and Shah [32], with some modifications. $52.5 \mu \mathrm{l}$ of extract was mixed with $200 \mu \mathrm{l}$ HippurylL-Histidyl-L-Leucine (HHL) solution (3.8 mM HHL, $0.01 \mathrm{M}$ sodium borate buffer, $0.3 \mathrm{M} \mathrm{NaCl}, \mathrm{pH} 8.3$ ) and 2 mU ACE (from rabbit lung; Sigma Aldrich, Saint Louis, Missouri, USA). After $30 \mathrm{~min}$ of incubation at $37^{\circ} \mathrm{C}$, the hippuric acid was extracted with $1.7 \mathrm{ml}$ ethyl acetate. The mixture was centrifuged and $1.5 \mathrm{ml}$ of the organic phase (ethyl acetate) was transferred into a fresh test tube and evaporated to dryness on a water bath for $15 \mathrm{~min}$ at $100^{\circ} \mathrm{C}$. The residue containing hippuric acid was dissolved in $1 \mathrm{ml}$ deionised water and the solution absorbance was measured at $228 \mathrm{~nm}$. The percentage of inhibition was calculated as follows:

$$
\text { ACE-inhibition }=[1-(\mathrm{A}-\mathrm{C}) /(\mathrm{B}-\mathrm{D})] \times 100
$$

where $\mathrm{A}$ is the absorbance with ACE, HHL and ACEinhibitory sample, B is the absorbance with ACE and HHL without ACE-inhibitory sample, $\mathrm{C}$ is the absorbance with HHL and ACE-inhibitory sample without ACE and $\mathrm{D}$ is the absorbance with HHL without ACE and ACE-inhibitory sample.

\subsection{Analysis of the Extracts by RP-HPLC}

The extracts were separated by reversed-phase high performance liquid chromatography (RP-HPLC) (Hewlett Packard Series 1100, Agilent Technologies, Waldbronn, Germany) according to the method developed by Broncano et al. [27]. $100 \mu \mathrm{l}$ of extracts was injected, and the components were separated on a Inertsil ODS-3, C8, Ph3 column $(4.6 \times 250 \mathrm{~mm}, 5 \mu \mathrm{m}$, GL Science, Tokio, Japan) using a linear gradient of acetonitrile $(10 \%-40 \%$, in 33 $\min$ ) containing $0.08 \%$ trifluoroacetic acid (TFA) at a flow rate of $1.0 \mathrm{ml} / \mathrm{min}$. The compounds $(<3 \mathrm{kDa})$ were detected at 214 and $280 \mathrm{~nm}$.

\subsection{Statistical Analysis}

Means and standard error of the mean $(n=10$ within each batch) were obtained from the analytical experiments. Results were analysed using an ANOVA test using the GLM procedure of SPSS 15.0 (SPSS Institute, Chicago, Illinois, USA). The level of significance was set to $p$ $<0.05$.

\section{Results and Discussion}

\subsection{Iberian and Dry Cured Ham}

\subsubsection{Proteolysis Parameters}

Protein percentage and non protein, amino acid and peptide nitrogen values of samples are presented in Table 1. Protein content ranged from $68 \%$ in dry cured ham to $63 \%$ in Iberian ham. Non significant differences were found between samples $(p>0.05)$. These values are consistent with the results described for cured ham [33] and Iberian ham [34].

NPN content ranged from 26.7 to $23.6 \mathrm{mg} \cdot \mathrm{N} / \mathrm{g}$ d.m. for cured and Iberian ham respectively and was similar to the values found in other studies [35,36], Differences were significant between cured and Iberian ham samples $(\mathrm{p}<0.020)$.

Regarding PN values, Iberian ham showed significantly higher values than cured ham $(4.9 \mathrm{mg} \cdot \mathrm{N} / \mathrm{g}$ d.m. vs. $2.8 \mathrm{mg} \cdot \mathrm{N} / \mathrm{g} \mathrm{d}$.m., respectively). These differences could be ascribed to the different length of the ripening period in these products $(>18$ moths for Iberian ham versus 6 moths for cured ham), which could have led to a higher proteolysis intensity in Iberian ham. In this sense, Martín et al. [35] described that PN content depended on the duration of the ham processing, showing that the longer the ripening period the higher $\mathrm{PN}$ content.

Values obtained for AN content in samples were 13.2 $\mathrm{mg} \cdot \mathrm{N} / \mathrm{g}$ d.m. and $16.9 \mathrm{mg} \cdot \mathrm{N} / \mathrm{g} \mathrm{d} . \mathrm{m}$. for Iberian and cured ham, respectively (Table 1). It is well known that amino acid fraction is the most abundant non protein nitrogen in ham, being more than $75 \%$ of non-protein nitrogen in the final product [35]. This fraction tends to increase as the temperature rises during the process (drying and cellar period) [35]. Therefore, the significantly lowest content of AN in Iberian ham despite of the long period at room temperature $\left(15^{\circ} \mathrm{C}-25^{\circ} \mathrm{C}\right)$ in the cellar stage, could be

Table 1. Protein content $(\%)$, non protein nitrogen (NPN) $\left(\mathrm{mg} \cdot \mathrm{N} / \mathrm{g}\right.$ dry matter), amino acid nitrogen (AN) $\left(\mathrm{mg} \cdot \mathrm{N} \cdot \mathrm{gr}^{-1}\right.$ dry matter) and peptidic nitrogen $(\mathrm{PN})\left(\mathrm{mg} \cdot \mathrm{N} \cdot \mathrm{gr}^{-1}\right.$ dry matter) of cured ham (CH) and Iberian ham (IH).

\begin{tabular}{ccccc}
\hline & Protein & NPN & AN & PN \\
\hline CH & $68 \pm 5.1$ & $26.7 \pm 2.2$ & $17 \pm 1.3$ & $2.9 \pm 0.5$ \\
IH & $63.7 \pm 5$ & $23.6 \pm 2.8$ & $13.2 \pm 1.5$ & $4.9 \pm 0.9$ \\
$\mathbf{p}$ & ns & $<0.020$ & $<0.001$ & $<0.001$ \\
\hline \multicolumn{2}{l}{ Results are expressed as means \pm standard error. }
\end{tabular}


due to the fact that amino acids generated in this period could react with carbonyl groups (Maillard reactions) or suffer degradation phenomena (Strecker degradation), leading to compounds responsible for flavour [37,38].

\subsubsection{Antioxidant Effect}

Results showed that ham extracts presented antioxidant activity (RSA and MQA) (Table 2). These results are also corroborated by Escudero et al. [39] who suggested that dry cured ham contained peptides with antioxidant activity. In this sense, antioxidant activity of meat protein extracts have been demonstrated in numerous studies to be related to hydrolysates made from pork, collagen from bovine, pig and venison [25,40-42]. In other studies, several authors found antioxidant activity in extracts from other meat product as fermented or dry cured sausage [18,26,27].

When results were treated statistically, significant differences $(p<0.001)$ appeared between hams. The antioxidant activity was higher in Iberian ham for both DPPH radical scavenging and metal chelating effect. This fact is probably due to a more intense generation of proteolysis compounds during processing of Iberian ham, where the ripening period is much longer than cured ham. In this sense, several studies have demonstrated the relationship between levels of free amino acids and peptides with antioxidant activity (RSA and MQA) found in different protein hydrolysates $[40,43,44]$.

\subsubsection{ACE Inhibitory Activity}

Percentage of ACE inhibitory activity for ham extracts is shown in Table 2. In light of the results, it is possible to conclude that both ham extracts presented ACE inhibitory activity. This is in agreement with results showed by Escudero et al. [39], who found antihypertensive peptides in dry cured ham extracts. In relation to this observation, other studies also found ACE inhibitory activity in meat protein hydrolysates, with similar values to the ones found in our work $[15,16,45,46]$. On the other hand, there were not significant differences between hams for ACE inhibitory activity values. This is difficult to explain considering the higher quantity of LMW com-

Table 2. Antioxidant effect expressed as DPPH radical scavenging activity (RSA) (\%), metal chelating activity (MQA) (\%) and antihypertensive activity expressed as ACE-inhibitory (ACEI) activity (\%) of cured ham $(\mathrm{CH})$ and Iberian ham (IH) extracts.

\begin{tabular}{cccc}
\hline & RSA & MQA & ACEI activity \\
\hline CH & $41.1 \pm 4.2$ & $54.8 \pm 1.5$ & $35.9 \pm 4.6$ \\
IH & $58.3 \pm 4.3$ & $67.9 \pm 2.8$ & $37.3 \pm 8.2$ \\
p & $<0.001$ & $<0.001$ & ns \\
\hline
\end{tabular}

Results are expressed as means \pm standard error. pounds $(<3 \mathrm{kDa})$ in Iberian ham promoted by a more intense proteolysis in this product.

\subsubsection{Analysis of the Extracts by RP-HPLC}

As it can be observed in Table 3, nine peaks have been separated in both types of ham. Differences between Iberian and cured ham have been found in the size of the peaks expressed as area arbitrary units (Table 3). Most of the peaks are presented in higher quantities in Iberian ham samples, peaks P2, P3, P4, P5 and P9 being significantly more abundant in these samples. This is in good agreement with previous results described by Martin et al. [37], who found higher areas of chromatogram peaks in ham as length of processing increased, causing higher content of proteolysis compounds.

Therefore, antioxidant and antihypertensive activity of the extracts can be promoted by some of these compounds. The identification and study of these compounds separately is currently being carried out in a parallel work by our research group.

\subsection{La Serena and Ewe's Milk Cheese}

\subsubsection{Proteolysis Parameters}

Protein percentage, non protein, peptide and aminoacid nitrogen values are shown in Table 4. Protein percentage was similar in both types of cheese, around 35\%. Other cheeses made from ewe's milk also presented similar values [47].

Content in NPN was $14.98 \mathrm{mg} \cdot \mathrm{N} / \mathrm{g}$ d.m. for ewe's milk cheese and $18.45 \mathrm{mg} \cdot \mathrm{N} / \mathrm{g} \mathrm{d} . \mathrm{m}$. for La Serena cheese, this last value being significantly higher. Therefore, it seems that proteolysis phenomena occurring during cheese processing is more intense in La Serena cheese. This was already mentioned by Varnam and Sutherland [48] who suggested that proteolysis in soft cheeses (such as La

Table 3. Area arbitrary units of fractions separated by RPHPLC from Iberian ham (IH) and cured ham (CH) extracts.

\begin{tabular}{cccc}
\hline Peaks & IH & CH & p \\
\hline P1 & $9093.1 \pm 2322.9$ & $9150.1 \pm 2180.7$ & ns \\
P2 & $17644.1 \pm 1719.1$ & $15809.4 \pm 661.8$ & $<0.05$ \\
P3 & $14850.6 \pm 1101.9$ & $13759.3 \pm 719.3$ & $<0.05$ \\
P4 & $7598.8 \pm 1596.9$ & $5816.9 \pm 803.6$ & $<0.05$ \\
P5 & $5923.2 \pm 1289.1$ & $4654 \pm 898.8$ & $<0.05$ \\
P6 & $899 \pm 134.2$ & $807.5 \pm 92.5$ & $\mathrm{~ns}$ \\
P7 & $5504.3 \pm 2121.8$ & $4447.5 \pm 887$ & $\mathrm{~ns}$ \\
P8 & $8086.7 \pm 1615.7$ & $6888.8 \pm 905.8$ & $\mathrm{~ns}$ \\
P9 & $6721 \pm 1402$ & $5487.8 \pm 602.5$ & $<0.05$ \\
\hline Results are expressed as means \pm standard error. &
\end{tabular}

Results are expressed as means \pm standard error. 
Serena) was more pronounced than in hard cheese. In this sense, various authors suggested that differences in NPN in cheese were caused by the type of rennet used in cheese making $[49,50]$. In this sense, cheese made with plant rennet (such as La Serena cheese) showed higher amount of NPN compared to cheese made with animal rennet (ewe's milk cheese) [47,51-53]. In this sense, values for PN were also significantly higher in La Serena cheese in comparison to ewe's milk cheese in the present research $(3.0 \mathrm{mg} \cdot \mathrm{N} / \mathrm{g}$ d.m. vs. $1.3 \mathrm{mg} \cdot \mathrm{N} / \mathrm{g} \mathrm{d}$ d.m., respectively) (Table 4), which is in agreement with Sousa and Malcata [54] and Tejada et al. [55] who found higher content of PN in cheese made with plant rennet.

On the other hand, values for AN were $2.1 \mathrm{mg} \cdot \mathrm{N} / \mathrm{g}$ d.m. and $3.5 \mathrm{mg} \cdot \mathrm{N} / \mathrm{g}$ d.m. in La Serena and ewe's milk cheese, respectively, these values being significantly different (Table 4). This seems to contradict the fact that proteolysis phenomena occurs more intensely in La Serena cheese. However, Yvon and Rijnen [56] explained that amino acids could suffer some transformations during processing, resulting in flavour compounds.

\subsubsection{Antioxidant Effect}

Table 5 shows values for antioxidant activity of cheese extracts expressed as percentage of DPPH inhibition (RSA) and chelating effect (MQA). Other authors have found antioxidant activity quantified as RSA in cheese [57] but also in milk [58], yoghurt [24] and serum protein [59]. On the other hand, antioxidant activity expressed as

Table 4. Protein content $(\%)$, non protein nitrogen (NPN) $\left(\mathrm{mg} \cdot \mathrm{N} \cdot \mathrm{gr}^{-1}\right.$ dry matter), amino acid nitrogen $(\mathrm{AN})\left(\mathrm{mg} \cdot \mathrm{N} \cdot \mathrm{gr}^{-1}\right.$ dry matter) and peptidic nitrogen $(\mathrm{PN})\left(\mathrm{mg} \cdot \mathrm{N} \cdot \mathrm{gr}^{-1}\right.$ dry matter) of matured ewe's milk cheese (MC) and La Serena cheese (SC).

\begin{tabular}{ccccc}
\hline & Protein & NPN & AN & PN \\
\hline MC & $35.2 \pm 0.8$ & $15 \pm 1.7$ & $3.6 \pm 0.4$ & $1.3 \pm 0.3$ \\
SC & $35.6 \pm 1.7$ & $18.4 \pm 2.1$ & $2.2 \pm 0.3$ & $3 \pm 0.6$ \\
p & ns & $<0.001$ & $<0.001$ & $<0.001$ \\
\hline
\end{tabular}

Results are expressed as means \pm standard error.

Table 5. Antioxidant effect expressed as DPPH radical scavenging activity (RSA) (\%), metal chelating activity (MQA) (\%) and antihypertensive activity expressed as ACE-inhibitory (ACEI) activity (\%) of matured ewe's milk cheese (MC) and La Serena cheese (SC) extracts.

\begin{tabular}{cccc}
\hline & RSA & MQA & ACEI activity \\
\hline MC & $10.1 \pm 4.1$ & $60.5 \pm 1.9$ & $81.4 \pm 7.5$ \\
SC & $78.1 \pm 5.6$ & $52.4 \pm 1.1$ & $80.8 \pm 5.0$ \\
$\mathbf{p}$ & $<0.001$ & $<0.001$ & $\mathrm{~ns}$ \\
\hline
\end{tabular}

Results are expressed as means \pm standard error.
MQA has been shown in milk [58] and yoghurt [24]. It is observed that La Serena cheese extract presented significantly higher values of RSA in comparison to matured cheese. On the contrary, matured cheese extract showed higher values of MQA. One possible explanation to this fact might be that LMW compounds generated in these products during processing could be different, and therefore may present different way of action related to its antioxidant activity. In fact, Broncano et al. [27] suggested that different LMW compounds isolated from Iberian chorizo showed different antioxidant mechanisms.

\subsubsection{ACE Inhibitory Activity}

All extracts showed ACEI activity, with values ranging from $81.4 \%$ for matured cheese to $80.8 \%$ for La Serena cheese (Table 5). These data are consistent with those found by other authors in different cheeses, also showing high values of ACEI activity [11,32,60,61]. By contrast, Torres-Llánez et al. [12] described lower antihypertensive activity values than ours in fresh cheese. In this sense, some authors have reported the important role of the ripening process in the formation of ACE inhibitory peptides, describing the absence of these peptides in fresh cheese [62].

Non significant differences were found between samples related to this activity $(\mathrm{p}>0.05)$. Therefore, it seems that a more intense proteolysis in La Serena cheese does not result in a higher ACEI activity. This is in contradiction to results shown by other authors who proposed that cheese extracts, containing more quantity of peptides $<3$ $\mathrm{kDa}$, show a higher ACEI activity $[62,63]$.

\subsubsection{Analysis of the Extracts by RP-HPLC}

It is observed that the number of peaks is higher in La Serena cheese than in matured ewe's milk cheese (31 versus 12 peaks) (Table 6). This results confirms the fact that proteolysis phenomena occurs more intensely in La Serena cheese, producing a higher quantity of LMW compounds $<3 \mathrm{Kda}$ (such as peptides). Size of the peaks expressed as area arbitrary units is presented in Table 6. Most abundant peaks were P4, P5, P8, P10, P12, P5 and P12 peaks showing the highest area in matured cheese extracts. Therefore, it would be interesting to isolate, identify and study separately antioxidant and antihypertensive activity of these compounds in order to explain the antioxidant and antihypertensive activity of the extracts.

\section{Conclusion}

Ham and cheese samples showed antioxidant and antihypertensive effect. Iberian ham showed higher antioxidant activity probably caused by a more intense proteolysis during processing compared to cured ham. However, this 
Table 6. Area arbitrary units of fractions separated by RPHPLC from La Serena cheese (SC) and matured ewe's milk cheese (MC) extracts.

\begin{tabular}{|c|c|c|c|}
\hline Peaks & $\mathrm{SC}$ & $\mathrm{MC}$ & $\mathrm{p}$ \\
\hline $\mathrm{P} 1$ & - & $3503.6 \pm 739.3$ & - \\
\hline $\mathrm{P} 2$ & $864.1 \pm 304.1$ & - & - \\
\hline P3 & - & $4716.5 \pm 395.1$ & - \\
\hline $\mathrm{P} 4$ & $7080.8 \pm 784.7$ & $3211.4 \pm 328.9$ & $<0.001$ \\
\hline P5 & - & $9508.99 \pm 2196.28$ & - \\
\hline P6 & $3079.5 \pm 1149.5$ & - & - \\
\hline P7 & $2586.7 \pm 463.9$ & - & - \\
\hline P8 & $7315.2 \pm 798$ & $6445.5 \pm 3362.3$ & ns \\
\hline P9 & - & $539.3 \pm 62.2$ & - \\
\hline P10 & $6920.5 \pm 1531.3$ & $5190.7 \pm 680.3$ & $<0.05$ \\
\hline $\mathrm{P} 11$ & $489.9 \pm 140.8$ & - & - \\
\hline $\mathrm{P} 12$ & $5216.6 \pm 1178.8$ & $11480.7 \pm 1290.3$ & $<0.001$ \\
\hline $\mathrm{P} 13$ & $876.7 \pm 292.3$ & $703.2 \pm 102.6$ & ns \\
\hline $\mathrm{P} 14$ & $626.4 \pm 345.5$ & $1860.5 \pm 229.5$ & $<0.001$ \\
\hline $\mathrm{P} 15$ & $1471.5 \pm 284.9$ & - & - \\
\hline $\mathrm{P} 16$ & $629.8 \pm 178.5$ & - & - \\
\hline P17 & $469.2 \pm 164.2$ & - & - \\
\hline P18 & $550.5 \pm 92.8$ & - & - \\
\hline P19 & $1727.7 \pm 614.3$ & - & - \\
\hline $\mathrm{P} 20$ & $1482.3 \pm 397.2$ & $1462.4 \pm 377.2$ & ns \\
\hline $\mathrm{P} 21$ & $824.9 \pm 253.7$ & - & - \\
\hline $\mathrm{P} 22$ & $442.6 \pm 108.7$ & - & - \\
\hline $\mathrm{P} 23$ & $1630.5 \pm 566.1$ & - & - \\
\hline $\mathrm{P} 24$ & - & $681.6 \pm 99.1$ & - \\
\hline $\mathrm{P} 25$ & $2032.4 \pm 511$ & - & - \\
\hline P26 & $1091.9 \pm 376.3$ & - & - \\
\hline $\mathrm{P} 27$ & $1650.3 \pm 496.4$ & - & - \\
\hline P28 & $738.5 \pm 234.6$ & - & - \\
\hline P29 & $964.6 \pm 229.1$ & - & - \\
\hline P30 & $590.5 \pm 161$ & - & - \\
\hline P31 & $1708.3 \pm 350.2$ & - & - \\
\hline P32 & $939.8 \pm 191.2$ & - & - \\
\hline P33 & $797.1 \pm 224.6$ & - & - \\
\hline P34 & $618.7 \pm 164.9$ & - & - \\
\hline P35 & $2011 \pm 260.5$ & - & - \\
\hline P36 & $2135.5 \pm 729.9$ & - & - \\
\hline
\end{tabular}

Results are expressed as means \pm standard error. relationship could not be established for the antihypertensive activity in this product. On the other hand, La Serena cheese did not show higher antioxidant or antihypertensive effect despite of a more intense proteolysis in this product. Therefore, it would be interesting to identify and study separately antioxidant and antihypertensive activity of low molecular weight compounds isolated from samples, in order to explain the antioxidant and antihypertensive activity of the obtained extracts.

\section{REFERENCES}

[1] E. Fernández-García, M. Carbonell, J. Calzada and M. Núñez, "Seasonal Variation of the Free Fatty Acids Contents of Spanish Ovine Milk Cheeses Protected by a Designation of Origin: A Comparative Study," Intenational Dairy Journal, Vol. 16, No. 3, 2006, pp. 252-261. doi:10.1016/i.idairyj.2005.02.010

[2] F. Jiménez-Colmenero, J. Ventanas and F. Toldrá, "Nutritional Composition of Dry-Cured Ham and Its Role in a Healthy Diet," Meat Science, Vol. 84, No. 4, 2010, pp. 585-593. doi:10.1016/j.meatsci.2009.10.029

[3] M. Carbonell, M. Núñez and E. Fernández-García, "Evolution of the Volatile Components of Ewe Raw Milk La Serena Cheese during Ripening. Correlation with Flavour Characteristics," Le Lait, Vol. 82, No. 6, 2002, pp. 683698. doi:10.1051/lait:2002042

[4] M. Fernández, J. A. Ordóñez, I. Cambero, C. Santos, C. Pin and L. de la Hoz, "Fatty Acid Compositions of Selected Varieties of Spanish Dry Ham Related to Their Nutritional Implications," Food Chemistry, Vol. 101, No. 1, 2007, pp. 107-112. doi:10.1016/j.foodchem.2006.01.006

[5] A. Revello Chion, E. Tabacco, D. Giaccone, P. G. Peiretti, G. Battelli and G. Borreani, "Variation of Fatty Acid and Terpene Profiles in Mountain Milk and 'Toma Piemontese' Cheese as Affected by Diet Composition in Different Seasons," Food Chemistry, Vol. 121, No. 2, 2010, pp. 393-399. doi:10.1016/j.foodchem.2009.12.048

[6] H. Korhonen and A. Pihlanto, "Food-Derived Bioactive Peptides Opportunities for Designing Future Foods," Current Pharmaceutical Design, Vol. 9, No. 16, 2003, pp. 1297-1308. doi: $10.2174 / 1381612033454892$

[7] M. Miguel, M. M. Contreras, I. Recio and A. Aleixandre, "ACE-Inhibitory and Antihypertensive Properties of a Bovine Casein Hydrolysate," Food Chemistry, Vol. 112, No. 1, 2009, pp. 211-214. doi:10.1016/j.foodchem.2008.05.041

[8] A. Pihlanto, T. Virtanen and H. Korhonen, "Angiotensin I Converting Enzyme (ACE) Inhibitory Activity and Antihypertensive Effect of Fermented Milk," International Dairy Journal, Vol. 20, No. 1, 2010, pp. 3-10. doi:10.1016/j.idairyj.2009.07.003

[9] B. Hernández-Ledesma, M. Ramos, I. Recio and L. Amigo, "Effect of $\beta$-Lactoglobulin Hydrolysis with Thermolysin under Denaturing Temperatures on the Release of Bioactive Peptides," Journal of Chromatography A, Vol. 1116, No. 1-2, 2006, pp. 31-37. doi:10.1016/j.chroma.2006.03.006 
[10] B. Hernández-Ledesma, M. Ramos and J. A. Gómez-Ruiz, "Bioactive Components of Ovine and Caprine Cheese Whey," Small Ruminant Research, Vol. 101, No. 1, 2011, pp. 196-204. doi:10.1016/j.smallrumres.2011.09.040

[11] J. A. Gómez-Ruiz, G. Taborda, L. Amigo, I. Recio and M. Ramos, "Identification of ACE Inhibitory Peptides in Different Spanish Cheeses by Tandem Mass Spectrometry," European Food Research and Technology, Vol. 223, No. 5, 2006, pp. 595-601. doi:10.1007/s00217-005-0238-0

[12] M. J. Torres-Llanez, A. F. González-Córdova, A. Hernández-Mendoza, H. S. García and B. Vallejo-Córdoba, "Angiotensin-Converting Enzyme Inhibitory Activity in Mexican Fresco Cheese," Journal of Dairy Science, Vol. 94, No. 8, 2011, pp. 3794-3800. doi:10.3168/jds.2011-4237

[13] A. Jang and M. Lee, "Purification and Identification of Angiotensin Converting Enzyme Inhibitory Peptides from Beef Hydrolysates," Meat Science, Vol. 69, No. 4, 2005, pp. 653-661. doi:10.1016/j.meatsci.2004.10.014

[14] A. M. Ahhmed and M. Muguruma, "A Review of Meat Protein Hydrolysates and Hypertension," Meat Science, Vol. 86, No. 1, 2010, pp. 110-118. doi:10.1016/j.meatsci.2010.04.032

[15] E. Escudero, M. A. Sentandreus, K. Arihara and F. Toldrá, "Angiotensin I-Converting Enzyme Inhibitory Peptides Generated from in Vitro Gastrointestinal Digestion of Pork Meat," Journal of Agricultural and Food Chemistry, Vol. 58, No. 5, 2010, pp. 2895-2901. doi:10.1021/jf904204n

[16] A. M. Sentandreu and F. Toldra, "Evaluation of ACE Inhibitory Activity of Dipeptides Generated by the Action of Porcine Muscle Dipeptidyl Peptidases," Food Chemistry, Vol. 102, No. 2, 2007, pp. 511-515. doi:10.1016/i.foodchem.2006.04.018

[17] K. Arihara and M. Ohata, "Bioactive Compounds in Meat,” In: F. Toldrá, Ed., Meat Biotechnology, Aomori, Japan, 2008, pp. 231-249. doi:10.1007/978-0-387-79382-5_11

[18] T. Vaštag, L. Popović, S. Popović, L. Petrović and D. Peričin, "Antioxidant and Angiotensin-I Converting Enzyme Inhibitory Activity in the Water-Soluble Protein Extract from Petrovac Sausage (Petrovská Kolbása)," Food Control, Vol. 21, No. 9, 2010, pp. 1298-1302. doi:10.1016/j.foodcont.2010.03.004

[19] K. Suetsuna, H. Ukeda and H. Ochi, "Isolation and Characterization of Free Radical Scavenging Activities Peptides Derived from Casein," Journal of Nutritional Biochemistry, Vol. 11, No. 3, 2000, pp. 128-131. doi:10.1016/S0955-2863(99)00083-2

[20] S. G. Rival, C. G. Boeriu and H. J. Wichers, "Caseins and Casein Hydrolysates. 2. Antioxidative Properties and Relevance to Lipoxygenase Inhibition," Journal of Agricultural and Food Chemistry, Vol. 49, No. 1, 2001, pp. 295302. doi:10.1021/jf0003911

[21] S. Sakanaka, Y. Tachibana, N. Ishihara and L. R. Juneja, "Antioxidant Properties of Casein Calcium Peptides and Their Effects on Lipid Oxidation in Beef Homogenates," Journal of Agricultural and Food Chemistry, Vol. 53, No. 2, 2005, pp. 464-468. doi:10.1021/jf0487699

[22] B. Hernández-Ledesma, A. Dávalos, B. Bartolomé and L.
Amigo, "Preparation of Antioxidant Enzymatic Hydrolysates from Alphalactalbumin and Beta-Lactoglobulin. Identification of Active Peptides by HPLC-MS/MS," Journal of Agricultural and Food Chemistry, Vol. 53, No. 3, 2005, pp. 588-593. doi:10.1021/jf048626m

[23] M. M. Contreras, B. Hernández-Ledesma, L. Amigo, P. J. Martín-Álvarez and I. Recio, "Production of Antioxidant Hydrolyzates from a Whey Protein Concentrate with Thermolysin: Optimization by Response Surface Methodology," Food Science and Technology, Vol. 44, No. 1, 2011, pp. 9-15.

[24] K. H. Farvin, C. Baron, N. Nielsen, J. Otte and C. Jacobsen, "Antioxidant Activity of Yoghurt Peptides: Part 2Characterisation of Peptide Fractions," Food Chemistry, Vol. 123, No. 4, 2010, pp. 1090-1097. doi:10.1016/j.foodchem.2010.05.029

[25] A. Saiga, S. Tanabe and T. Nishimura, "Antioxidant Activity of Peptides Obtained from Porcine Myofibrillar Proteins by Protease Treatment," Journal of Agricultural and Food Chemistry, Vol. 51, No. 12, 2003, pp. 36613667. doi:10.1021/jf021156g

[26] W. Sun, H. Zhao, Q. Zhao, M. Zhao, B. Yang, N. Wu, et al., "Structural Characteristics of Peptides Extracted from Cantonese Sausage during Drying and Their Antioxidant Activities," Innovative Food Science and Emerging Technologies, Vol. 10, No. 4, 2009, pp. 558-563. doi:10.1016/j.ifset.2009.07.006

[27] J. M. Broncano, M. L. Timón, V. Parra, A. I. Andrés and M. J. Petrón, "Use of Proteases to Improve Oxidative Stability of Fermented Sausages by Increasing Low Molecular Weight Compounds with Antioxidant Activity," Food Research International, Vol. 44, No. 9, 2011, pp. 26552659. doi:10.1016/j.foodres.2011.05.011

[28] J. M. Broncano, J. Otte, M. J. Petrón, V. Parra and M. L. Timón, "Isolation and Identification of Low Molecular Weight Antioxidant Compounds from Fermented 'Chorizo' Sausages,” Meat Science, Vol. 90, No. 2, 2012, pp. 494-501. doi:10.1016/j.meatsci.2011.09.015

[29] Determination of Nitrogen Content, ISO 937:1978 Standard, In International Standards Meat and Meat Products, International Organization for Standardization, Geneva, 1978.

[30] M. J. Benito, F. Núñez, M. G. Córdoba, A. Martín and J. J. Córdoba, "Generation of Non-Protein Nitrogen and Volatile Compounds by Penicillium Chrysogenum Pg222 Activity on Pork Myofibrillar Proteins," Food Microbiology, Vol. 22, No. 6, 2005, pp. 513-519. doi:10.1016/j.fm.2004.11.010

[31] V. Parra, J. Otte, M. J. Petrón, J. M. Broncano and M. L. Timón, "Identification of Radical Scavenging Peptides (<3kDa) from Burgos-Type Cheese," LWT-Food Science and Technology, in Revision, 2013.

[32] L. Ong and N. P. Shah, "Release and Identification of Angiotensin-Converting Enzyme-Inhibitory Peptides as Influenced by Ripening Temperatures and Probiotic Adjuncts in Cheddar Cheeses," Food Science and Technology, Vol. 41, No. 9, 2008, pp. 1555-1566.

[33] M. Clariana, L. Guerrero, C. Sárraga and J. A. GarciaRegueiro, "Effects of High Pressure Application (400 and 
$900 \mathrm{MPa}$ ) and Refrigerated Storage Time on the Oxidative Stability of Sliced Skin Vacuum Packed Dry-Cured Ham," Meat Science, Vol. 90, No. 2, 2012, pp. 323-329. doi:10.1016/i.meatsci.2011.07.018

[34] T. Pérez-Palacios, J. Ruiz, J. M. Barat, M. C. Aristoy and T. Antequera, "Influence of Pre-Cure Freezing of Iberian Ham on Proteolytic Changes throughout the Ripening Process," Meat Science, Vol. 85, No. 1, 2010, pp. 121-126. doi:10.1016/i.meatsci.2009.12.015

[35] L. Martín, J. J. Córdoba, T. Antequera, M. L. Timón and J. Ventanas, "Effects of Salt and Temperature on Proteolysis during Ripening of Iberian Ham," Meat Science, Vol. 49, No. 2, 1998, pp. 145-153. doi:10.1016/S0309-1740(97)00129-0

[36] M. Prevolnik, M. Škrlep, L. Janeš, S. Velikonja-Bolta, D. Škorjanc and M. Čandek-Potokar, "Accuracy of Near Infrared Spectroscopy for Prediction of Chemical Composition, Salt Content and Free Amino Acids in Dry-Cured Ham," Meat Science, Vol. 88, No. 2, 2011, pp. 299-304. doi:10.1016/j.meatsci.2011.01.007

[37] L. Martín, T. Antequera, J. Ventanas, R. Benítez-Donoso and J. J. Córdoba, "Free Amino Acids and Other NonVolatile Compounds Formed during Processing of Iberian Ham," Meat Science, Vol. 59, No. 4, 2001, pp. 363-368. doi:10.1016/S0309-1740(01)00088-2

[38] R. Virgili, G. Saccani, L. Gabba, E. Tanzi and C. S. Bordini, "Changes of Free Amino Acids and Biogenic Amines during Extended Ageing of Italian Dry-Cured Ham," LWT-Food Science and Technology, Vol. 40, No. 5, 2007, pp. 871-878. doi:10.1016/i.lwt.2006.03.024

[39] E. Escudero, M. C. Aristoy, H. Nishimura, K. Arihara and F. Toldrá, "Antihypertensive Effect and Antioxidant Activity of Peptide Fractions Extracted from Spanish DryCured Ham," Meat Science, Vol. 91, No. 3, 2012, pp. 306-311. doi:10.1016/j.meatsci.2012.02.008

[40] B. Li, F. Chen, X. Xang, B. Ji and Y. Wu, "Isolation and Identification of Antioxidative Peptides from Porcine Collagen Hydrolysate by Consecutive Chromatography and Electrospray Ionization-Mass Spectrometry," Food Chemistry, Vol. 102, No. 4, 2007, pp. 1135-1143. doi:10.1016/j.foodchem.2006.07.002

[41] R. Ohba, T. Deguchi, M. Kishikawa, F. Arsyad, S. Morimura and K. Kida, "Physiological Functions of Enzymatic Hydrolysates of Collagen or Keratin Contained in Livestock and Fish Waste," Food Science and Technology Research, Vol. 9, No. 1, 2003, pp. 91-93. doi:10.3136/fstr.9.91

[42] E. K. Kim, S. J. Lee, B. T. Jeon, S. H. Moon, B. K. Kim and T. K. Park, "Purification and Characterisation of Antioxidative Peptides from Enzymatic Hydrolysates of Venison Protein," Food Chemistry, Vol. 114, No. 4, 2009, pp. 1365-1370. doi:10.1016/j.foodchem.2008.11.035

[43] H. C. Wu, H. M. Chen and C. Y. Shiau, "Free Amino Acids and Peptides as Related to Antioxidant Properties in Protein Hydrolysates of Mackerel (Scomber austriasicus)," Food Research International, Vol. 36, No. 9-10, 2003, pp. 949-957. doi:10.1016/S0963-9969(03)00104-2

[44] X. X. Li, L. J. Han and L. J. Chen, "In Vitro Antioxidant Activity of Protein Hydrolysates Prepared from Corn
Gluten Meal," Journal of the Science of Food and Agriculture, Vol. 88, No. 9, 2008, pp. 1660-1666. doi: $10.1002 /$ jsfa. 3264

[45] K. Katayama, E. H. Anggraeni, T. Mori, M. A. Ahhmed, S. Kawahara, M. Sugiyama, et al., "Porcine Skeletal Muscle Troponin Is a Good Source of Peptides with AngiotensinI Activity and Antihypertensive Effects in Spontaneously Hypertensive Rats," Journal of Agricultural and Food Chemistry, Vol. 56, No. 2, 2008, pp. 355-360. doi:10.1021/jf071408j

[46] M. Muguruma, M. A. Ahhmed, K. Katayama, S. Kawahara, M. Maruyama and T. Nakamura, "Identification of Pro-Drug Type Inhibitory Peptide Sourced from Porcine Myosin B: Evaluation of Its Antihypertensive Effects in Vivo," Food Chemistry, Vol. 114, No. 2, 2009, pp. 516522. doi:10.1016/j.foodchem.2008.09.081

[47] E. Galán, F. Prados, A. Pino, L. Tejada and J. Fernández-Salguero, "Influence of Different Amounts of Vegetable Coagulant from Cardoon Cynara cardunculus and Calf Rennet on the Proteolysis and Sensory Characteristics of Cheeses Made with Sheep Milk," International Dairy Journal, Vol. 18, No. 1, 2008, pp. 93-98. doi:10.1016/j.idairyj.2007.06.003

[48] A. H. Varnam and J. P. Sutherland, "Milk and Milk Products," In: C. Y. Hall, Ed., Technology, Chemistry and Microbiology (Food Products Series 1), London, 1994.

[49] M. Nuñez, B. F. del Pozo, M. A. Rodríguez, P. Gaya and M. Medina, "Effect of Vegetable and Animal Rennet on Chemical, Microbiological, Rheological and Sensory Characteristics of La Serena Cheese," Journal of Dairy Research, Vol. 58, No. 4, 1991, pp. 511-519. doi: 10.1017/S0022029900030120

[50] B. F. del Pozo, P. Gaya, M. Medina, M. A. R. Marín and M. Nuñez, "Changes in Chemical and Rheological Characteristics of La Serena Ewes' Milk Cheese during Ripening," Journal of Dairy Research, Vol. 55, No. 3, 1988, pp. 457-464. doi:10.1017/S0022029900028715

[51] J. Fernández-Salguero and E. Sanjuán, "Influence of Vegetable and Animal Rennet on Proteolysis during Ripening in Ewes' Milk Cheese," Food Chemistry, Vol. 64, No. 2, 1999, pp. 177-183. doi:10.1016/S0308-8146(98)00149-6

[52] J. Fernández-Salguero, L. Tejada and R. Gómez, "Use of Powdered Vegetable Coagulant in the Manufacture of Ewe's Milk Cheeses," Journal of the Science of Food and Agriculture, Vol. 82, No. 4, 2002, pp. 464-468. doi: $10.1002 /$ jsfa. 1066

[53] F. J. Delgado, J. Rodríguez-Pinilla, J. González-Crespo, R. Ramírez and I. Roa, "Proteolysis and Texture Changes of a Spanish Soft Cheese ('Torta del Casar') Manufactured with Raw Ewe Milk and Vegetable Rennet during Ripening," International Journal of Food Science and Technology, Vol. 45, No. 3, 2010, pp. 512-519. doi:10.1111/j.1365-2621.2009.02157.x

[54] M. J. Sousa and F. X. Malcata, "Comparison of Plant and Animal Rennets in Terms of Microbiological, Chemical, and Proteolysis Characteristics of Ovine Cheese," Journal of Agricultural and Food Chemistry, Vol. 45, No. 1, 1997, pp. 74-81. doi:10.1021/jf9506601 
[55] L. Tejada, A. Abellán, J. M. Cayuela, A. Martínez-Cacha and J. Fernández-Salguero, "Proteolysis in Goats' Milk Cheese Made with Calf Rennet and Plant Coagulant," International Dairy Journal, Vol. 18, No. 2, 2008, pp. 139146. doi:10.1016/j.idairyj.2007.08.010

[56] M. Yvon and L. Rijnen, "Cheese Flavour Formation by Amino Acid Catabolism," International Dairy Journal, Vol. 11, No. 4-7, 2001, pp. 185-201. doi:10.1016/S0958-6946(01)00049-8

[57] S. Pritchard, M. Phillips and K. Kailasapathy, "Identification of Bioactive Peptides in Commercial Cheddar Cheese," Food Research International, Vol. 43, No. 5, 2010, pp. 1545-1548. doi:10.1016/j.foodres.2010.03.007

[58] S. Hogan, L. Zhang, H. Wang and K. Zhou, "Development of Antioxidant Rich Peptides from Milk Protein by Microbial Proteases and Analysis of Their Effects on Lipid Peroxidation in Cooked Beef," Food Chemistry, Vol. 117, No. 3, 2009, pp. 438-443. doi:10.1016/j.foodchem.2009.04.040

[59] X. Peng, Y. Xiong and B. Kong, "Antioxidant Activity of Peptide Fractions from Whey Protein Hydrolysates as Measured by Electron Spin Resonance," Food Chemistry, Vol. 113, No. 1, 2009, pp. 196-201. doi:10.1016/j.foodchem.2008.07.068
[60] T. Saito, T. Nakamura, H. Kitazawa, Y. Kawai and T. Itoh, "Isolation and Structural Analysis of Antihypertensive Peptides that Exist Naturally in Gouda Cheese," Journal of Dairy Science, Vol. 83, No. 7, 2000, pp. 1434-1440. doi:10.3168/jds.S0022-0302(00)75013-2

[61] J. A. Gómez-Ruiz, M. Ramos and I. Recio, "Identification and Formation of Angiotensin-Converting Enzyme-Inhibitory Peptides in Manchego Cheese by High Performance Liquid Chromatography Tandem Mass Spectrometry," Journal of Chromatography A, Vol. 1054, No. 1-2, 2004, pp. 269-277. doi:10.1016/j.chroma.2004.05.022

[62] A. Okamoto, H. Hanagata, E. Matsumoto, Y. Kawamura, Y. Koizumi and F. Yanagida, "Angiotensin I Converting Enzyme Inhibitory Activities of Various Fermented Milks," Bioscience, Biotechnology and Biochemistry, Vol. 59, No. 6, 1995, pp. 1147-1149. doi:10.1271/bbb.59.1147

[63] L. Lignitto, V. Cavatorta, S. Balzan, G. Gabai, G. Galaverna, E. Novelli, et al., "Angiotensin-Converting Enzyme Inhibitory Activity of Water-Soluble Extracts of Asiago D'Allevo Cheese," International Dairy Journal, Vol. 20, No. 1, 2010, pp. 11-17. doi:10.1016/j.idairyj.2009.07.001 